\title{
Critical design factors for polyvinyl alcohol hydrogel entrapping ammonia-oxidizing bacteria: biomass loading, distribution of dissolved oxygen, and bacterial liability
}

\author{
Nguyen Thi Minh ${ }^{1,2}$, Minkyu Choi ${ }^{3}$, Nohback Park ${ }^{4}$, Hyokwan Bae ${ }^{1^{\dagger}}$ \\ ${ }^{1}$ Department of Civil and Environmental Engineering, Pusan National University, Busan 46241, Republic of Korea \\ ${ }^{2}$ Environmental Biotechnology Laboratory, Institute of Biotechnology, Vietnam Academy of Science and Technology, 18 Hoang Quoc Viet, Cau Giay, \\ Hanoi 100000, Vietnam \\ ${ }^{3}$ Korea Dyeing \& Finishing Technology Institute, 92, Dalseocheon-ro, Seo-gu, Daegu 41706, Republic of Korea \\ ${ }^{4}$ Aquaculture Management Division, National Institute of Fisheries Science, 216 Giganghaean-ro, Gijang-eup, Gijang-gun, Busan, 46083, Republic of Korea
}

\begin{abstract}
The single-stage configuration of the partial nitritation (PN)-anaerobic ammonium oxidation (AMX) process is preferred due to low $\mathrm{pH}$ fluctuation and the low concentration of inhibitory $\mathrm{NO}_{2}^{-}$. The novel core-shell structure integrates ammonia-oxidizing reaction in the outer layer to protect AMX bacteria in the core gel bead from oxygen inhibition and provide $\mathrm{NO}_{2}^{-}$. Here, the initial activity of ammonia-oxidizing bacteria (AOB) in the outer layer was assessed by the specific oxygen uptake rate (OUR). AOB activity was positively correlated with biomass loading in the outer layer. A maximum OUR of $10.5 \mathrm{mg}-\mathrm{DO} / \mathrm{L}^{-\mathrm{h}}$ was achieved with $\mathrm{AOB}$ loading of $0.23 \mathrm{mg}-\mathrm{VSS}$ per bead. During $\mathrm{AOB}^{-}$enrichment, the $\mathrm{NO}_{2}^{-}$production rate was linearly increased up to $0.65 \mathrm{~kg}-\mathrm{N} / \mathrm{m}^{3}$-d for 17 days (PVA hydrogel packing ratio=17\%). The maximum oxygen penetration depth (OPD) was reduced from $966.7 \pm 52.3 \mu \mathrm{m}$ before enrichment to $333.3 \pm 36.4 \mu \mathrm{m}$ after the AOB enrichment. The liable bacteria were observed within a range of $165 \mu \mathrm{m}$ of the outer layer using the live and dead cell staining. Based on the OPD and liable cell distribution results, a minimal outer layer thickness of approximately $350 \mu \mathrm{m}$ was suggested to facilitate a successful PN-AMX process.
\end{abstract}

Keywords: Aerobic ammonium oxidation, Bacterial liability, Oxygen penetration, Oxygen uptake rate, PVA/alginate hydrogel

\section{Introduction}

Biological removal of nitrogen is achieved via two steps: nitrification and denitrification. In the nitrification step, nitrifying bacteria produce nitrite and nitrate, which are reduced to dinitrogen gas in the subsequent denitrification step. Nitrifying bacteria of ammonia-oxidizing bacteria (AOB) and nitrite-oxidizing bacteria (NOB) are sensitive to environmental conditions such as $\mathrm{pH}$, temperature, free ammonia, free nitric acid, and inorganic carbon limitations [1-3]. Moreover, due to the slow growth rate of nitrifiers, the start-up of the nitrification process requires a long stabilization period in sewage and industrial wastewater treatment plants [4, 5]. When the AOB is negatively affected by toxic elements, biomass washout is one of the most critical problems that lead to the failure of the nitrification process [6, 7]. Regardless, the poor settleability of the nitrifying biomass worsens the decrease in the biomass concentration in the nitrifying bioreactor [8]. To solve these problems, entrapment technology has been introduced in the nitrifying process. The moving bed biofilm reactor (MBBR) retains the biomass in biomass carriers without any recycle unit to maintain the high concentration of mixed liquor suspended solids (MLSS). The volumetric ammonia-oxidation rate is also greatly increased (up to $2 \sim 3 \mathrm{~kg}-\mathrm{N} / \mathrm{m}^{3}$-d) using whole-cell entrapment in poly (vinyl alcohol) (PVA) hydrogels $[9,10]$. It was proven that the resistance of AOB to toxic chemicals can be improved when they are immobilized in polymeric substances, such as alginate, chitosan, PVA, poly (ethylene glycol) (PEG), glutaraldehyde, etc. [11-13].

Entrapment technology using PVA was recently applied to the combined partial nitritation (PN) and anaerobic ammonium oxida-
This is an Open Access article distributed under the terms of the Creative Commons Attribution Non-Commercial License (http://creativecommons.org/licenses/by-nc/3.0/) which permits unrestricted non-commercial use, distribution, and reproduction in any medium, provided the original work is properly cited.

Copyright (C) 2021 Korean Society of Environmental Engineers
Received January 02, 2020 Accepted May 17, 2020

${ }^{\dagger}$ Corresponding author

Email: hyokwan.bae@pusan.ac.kr

Tel: +82-510-2392 Fax: +82-514-9574

ORCID: 0000-0002-2422-9411 
tion (AMX) process [14]. The conversion of half of the $\mathrm{NH}_{4}{ }^{+}$to $\mathrm{NO}_{2}^{-}$by $\mathrm{AOB}$ is the first step, followed by the production of nitrogen gas by the AMX bacteria. The combined PN-AMX process can theoretically reduce $60 \%$ of the aeration consumption, $100 \%$ of the carbon source demand, and $90 \%$ of sludge production, compared to the conventional biological nitrogen removal (BNR) process [15-17]. More than a hundred full-scale PN-AMX plants have been installed worldwide [18]. This PN-AMX process can be operated in two-stage reactors using separate oxic and anoxic reactors. Alternatively, the different configuration of the single-stage process utilizes the co-cultivation of AOB and AMX bacteria in aerobic conditions with a low level of dissolved oxygen (DO) at theoretical total nitrogen (TN) removal efficiency of $89 \%$ (Eq. (1)). The single-stage type is preferred over the two-stage type due to its lower $\mathrm{pH}$ fluctuations and relatively low concentrations of the inhibitory substance $\mathrm{NO}_{2}^{-}$[19-21]. The entrapment of $\mathrm{AOB}$ and AMX bacteria in the outer layer and the core bead of the core-shell structured PVA hydrogel, respectively, showed successful TN removal in a single-stage bioreactor [9].

$$
\begin{gathered}
\mathrm{NH}_{3}+0.85 \mathrm{O}_{2} \rightarrow \\
0.44 \mathrm{~N}_{2}+0.11 \mathrm{NO}_{3}^{-}+0.14 \mathrm{H}^{+}+1.42 \mathrm{H}_{2} \mathrm{O}
\end{gathered}
$$

The single-stage PN-AMX process is based on the biofilm system of heterogeneously distributed AOB and AMX bacteria. In general, AMX bacteria are reversibly and irreversibly inhibited with the DO concentrations of $2.5 \mathrm{mg} / \mathrm{L}$ and $5.0 \mathrm{mg} / \mathrm{L}$ [22-24]. In a previous study on the effects of the concentration of DO on the PN-AMX process, TN removal efficiency of $88.9 \%$ was achieved at a DO concentration of $1.21 \mathrm{mg} / \mathrm{L}$ but TN removal was reduced at a higher DO level [25]. As an optimum condition, a DO concentration of $1.1-1.7 \mathrm{mg} / \mathrm{L}$ is favorable for the single-stage $\mathrm{PN}-\mathrm{AMX}$ process [26]. The AOB of the outer layer acts as a protector of the AMX bacteria from oxygen inhibition. Hence, the DO profile in the entrapment system for the single-stage PN-AMX should be precisely characterized to identify the possible inhibition of AMX activity by oxygen penetration.

In our previous study, the novel entrapment technology using core-shell structured PVA hydrogel for PN-AMX was investigated in terms of design factor [14]. However, the minimization of the thickness of the outer layer of the core-shell structured PVA hydrogel was not considered. The mass transportation efficiency can be maximized with the minimum thickness to shorten the distance between AOB and AMX bacteria. To minimize the thickness of the outer layer, the fundamental knowledge on the distribution of oxygen and the liable cell is required. The excessively thin outer layer causes oxygen penetration into the core bead and the failure of AMX reaction due to the oxygen inhibition. Also, the thin outer layer restricts the AOB growth due to the limited space for the entrapment. Therefore, the thickness can be minimized until DO is completely depleted and sufficient space is provided for the liable nitrifying bacterial community. Therefore, in this study, the distribution of DO and bacterial viability were investigated in the micro-scale during the continuous operation of ammonia-oxidation as the basic information to design the thickness of the outer layer. Also, the special concerns were taken to the initial concentration of the nitrifying activated sludge used for the PVA hydrogel fabrication to maintain the high activity of ammonia-oxidation for the best DO depletion for the successful start-up.

\section{Materials and Methods}

\subsection{Fabrication of PVA Hydrogel Entrapping Nitrifying Vacteria}

The outer layer of the double-layered gel beads was fabricated using prepared blank core PVA/alginate gel beads using an interfacial cross-linking reaction [27]. First, the cross-linking agents of $\mathrm{B}(\mathrm{OH})_{3}$ and $\mathrm{CaCl}_{2}$ were diffused into 100 blank core beads in $250 \mathrm{~mL}$ of saturated $\mathrm{B}(\mathrm{OH})_{3}$ and $1 \% \mathrm{CaCl}_{2}(\mathrm{w} / \mathrm{v})$ for $5 \mathrm{~min}$. To construct the PVA/alginate outer layer, the 100 blank beads were immersed in $250 \mathrm{~mL} / \mathrm{L}$ of 15\% PVA (with a polymerization degree of 2000, Wako, Japan) and 2.0\% of sodium alginate (w/v) (Showa, Japan) mixed with the nitrifying biomass at a designated concentration. The nitrifying activated sludge was obtained from the bioreactor with moving bed biofilm showing selective $\mathrm{NO}_{2}^{-}$production over $\mathrm{NO}_{3}{ }^{-}$with an ammonia loading rate of $1.0 \mathrm{~kg}-\mathrm{N} / \mathrm{m}^{3}$-day [28]. By the molecular detection of the bacterial community, the relative abundance of $\mathrm{AOB}$ was about $80 \%$ for the nitrifying biofilm on the moving bed in a continuous mode [29]. However, the heterotrophic bacteria and NOB were also found. Thus, the volatile suspended solids (VSS) is defined as the mixture of the various functional bacterial group for organic carbon, ammonia, and nitrite in this study. By the diffusion of the cross-linking agents toward the bulk phase of the PVA/alginate with the nitrifying biomass, interfacial cross-linking for the outer layer occurred. Then, the beads were maintained in the newly prepared $\mathrm{B}(\mathrm{OH})_{3}-\mathrm{CaCl}_{2}$ solution at the same concentration for $1 \mathrm{~h}$ for hardening. Finally, the fabricated core-shell structured PVA/alginate gel beads were thoroughly washed with a large amount of distilled water and stored at $4^{\circ} \mathrm{C}$ until use. To measure the thickness of the outer layer according to the fabrication conditions, the beads were stored at $-70^{\circ} \mathrm{C}$ for $30 \mathrm{~min}$ and cut into two pieces along the center. The concentration of PVA in the outer layer was differentiated as $7.5 \%, 10 \%$, and $12.5 \%$ to identify the effect on the oxygen uptake rate (OUR). For the best activity of nitrifying bacteria, a range of biomass concentrations from $765 \pm 9$ to $4,219 \pm 34 \mathrm{mg}$-VSS/L were tested.

\subsection{Measurement of Nitrifying Activity}

The activity of AOB was measured based on the OUR test using a DO probe (YSI Model-58, USA). The culture medium for AOB consisted of $100 \mathrm{mg} / \mathrm{L}$ of $\mathrm{NH}_{4}{ }^{+}-\mathrm{N}$ and $171 \mathrm{mg} / \mathrm{L}$ of $\mathrm{HCO}_{3}{ }^{-} \mathrm{C}$. The basal medium consisted of 6 mg-P/L of $\mathrm{KH}_{2} \mathrm{PO}_{4}, 12 \mathrm{mg}-\mathrm{Mg} / \mathrm{L}$ of $\mathrm{MgSO}_{4} \cdot 7 \mathrm{H}_{2} \mathrm{O}, 48 \mathrm{mg}-\mathrm{Ca} / \mathrm{L}$ of $\mathrm{CaCl}_{2} \cdot 2 \mathrm{H}_{2} \mathrm{O}, 1 \mathrm{~mL} / \mathrm{L}$ of trace element solution I, and $1 \mathrm{~mL} / \mathrm{L}$ of trace element solution II. Trace element solution I consisted of $5 \mathrm{~g} / \mathrm{L}$ EDTA and $5 \mathrm{~g} / \mathrm{L} \mathrm{FeSO}_{4} \cdot 7 \mathrm{H}_{2} \mathrm{O}$. Trace element solution II consisted of $5 \mathrm{~g} / \mathrm{L}$ EDTA, $0.43 \mathrm{~g} / \mathrm{L} \mathrm{ZnSO} \cdot 7 \mathrm{H}_{2} \mathrm{O}$, $0.24 \mathrm{~g} / \mathrm{L} \mathrm{CoCl}_{2} \cdot 6 \mathrm{H}_{2} \mathrm{O}, 0.99 \mathrm{~g} / \mathrm{L} \mathrm{MnCl}_{2} \cdot 4 \mathrm{H}_{2} \mathrm{O}, 0.25 \mathrm{~g} / \mathrm{L} \mathrm{CuSO}_{4} \cdot 5 \mathrm{H}_{2} \mathrm{O}$, $0.22 \mathrm{~g} / \mathrm{L} \mathrm{Na}_{2} \mathrm{MoO}_{4} \cdot 2 \mathrm{H}_{2} \mathrm{O}, 0.19 \mathrm{~g} / \mathrm{L} \mathrm{NiCl} \cdot 6 \mathrm{H}_{2} \mathrm{O}, 0.21 \mathrm{~g} / \mathrm{L} \mathrm{Na}_{2} \mathrm{SeO}_{4}$. $10 \mathrm{H}_{2} \mathrm{O}$, and $0.014 \mathrm{~g} / \mathrm{L} \mathrm{H}_{3} \mathrm{BO}_{3}$. Ammonia was added to the basal medium in the required amounts in the form of $\left(\mathrm{NH}_{4}\right)_{2} \mathrm{SO}_{4}$. The solution for AOB was purged with ambient air to saturate DO 
for $30 \mathrm{~min}$. Then, 100 beads were added to the culture medium in a BOD bottle. The slope of the decrease in the DO concentration was calculated as an indicator of the $\mathrm{AOB}$ activity.

\subsection{Operation of Ammonia-oxidation in Continuous Mode}

A continuous bioreactor of 0.3-L was filled with the double-layered gel beads (17\% packing ratio) and operated for $17 \mathrm{~d}$ to increase the ammonia-oxidizing activity of the immobilized nitrifying bacteria in the gel beads. The same biomass of section 2.1 was utilized for the continuous operation of the bioreactor. The outer layer performing ammonia-oxidation was inoculated with 3,437 \pm 202 mg-VSS/L of nitrifying activated sludge. The average thickness of the outer layer was $2.26 \pm 0.28 \mathrm{~mm}$, and the hydraulic retention time (HRT) was $2.6 \sim 2.9 \mathrm{~h}$. The bioreactor was operated under dark conditions at $35^{\circ} \mathrm{C}$, and the $\mathrm{DO}$ concentration was maintained at $2.0 \mathrm{mg} / \mathrm{L}$. The basal medium was the same as that in Section 2.2. The concentration of $\mathrm{NH}_{4}{ }^{+}-\mathrm{N}$ was increased from 52.4 to 101.1 $\mathrm{mg} / \mathrm{L}$ in the influent. The molar ratio of $\mathrm{HCO}_{3}^{-}-\mathrm{C}$ to $\mathrm{NH}_{4}{ }^{+}-\mathrm{N}$ was maintained at 2:1 to prevent the sharp decrease in $\mathrm{pH}$. The stable $\mathrm{pH}$ was maintained at 7.2 7.5 in the bioreactor. After the acclimation of the ammonia-oxidizing activity in the outer layer, the gel beads were used to determine the DO penetration depth and liability distribution of the nitrifying bacteria in the PVA/alginate hydrogel.

\subsection{Distribution of DO in The PVA/alginate Hydrogel}

The oxygen microsensor (USOX-50, Unisense, Denmark) was loaded onto the micromanipulator (USMC-232, Unisense, Denmark) to measure the DO concentration in the outer layer with a step size of 2 or $3 \mu \mathrm{m}$. The holding unit fixes the bead at a certain position in the culture medium [14]. Before measurement, various DO concentrations $(0.5,2.0,4.0,6.0$, and $8.0 \mathrm{mg} / \mathrm{L})$ of the culture medium were adjusted by balancing the air and argon gas purging intensities. The DO concentrations were recorded for three beads by the logging software (SensorTrace PRO, version 3.1.3, Unisense, Denmark). The DO penetration depth was determined as the distance between the surface and the position exhibiting a DO of less than $0.2 \mathrm{mg} / \mathrm{L}$, which is the detection limit of the microelectrode system.

\subsection{Bacterial Distribution in the PVA Hydrogel}

After the acclimation of the ammonia-oxidizing activity in the outer layer, the cell density was measured using a live/dead bacterial viability staining kit (Molecular Probes, US) and a confocal laser scanning microscope (CLSM) (LSM 5 exciter, Carl-Zeiss, Germany). A double-layered gel bead was stained in a $0.3 \%(\mathrm{v} / \mathrm{v})$ diluted solution of staining agents at a total volume of $50 \mathrm{~mL}$ for $30 \mathrm{~min}$ per three hydrogel beads. The stained gel bead was thoroughly washed in a $50 \mathrm{~mL}$ washing solution of $0.85 \% \mathrm{NaCl}$ three times before measurement. For the live and dead cells, $530 \mathrm{~nm}$ for the green signal and $620 \mathrm{~nm}$ for the red signal were applied.

\section{Results and Discussion}

\subsection{Initial Ammonia-oxidizing Activity}

The initial ammonia-oxidizing activity was investigated to secure the effective protection of AMX bacteria from oxygen inhibition at the start-up stage of the single-stage nitrogen removal (Fig. S1). It was proven that PVA concentration is the most important factor that enhances the mechanical strength of the outer layer [14]. To assess the effect of the PVA concentration on the initial ammonia-oxidizing activity, the PVA concentration was adjusted to $7.5,10.0$, and $12.5 \%$ at a fixed nitrifying activated sludge concentration of $1,514 \pm 16 \mathrm{mg}-\mathrm{VSS} / \mathrm{L}$. A thick outer layer could load a higher amount of nitrifying activated sludge due to the larger volume available when the PVA concentration was increased. Nitrifying activated sludge of $0.02,0.03$, and $0.05 \mathrm{mg}$-VSS was immobilized per PVA/alginate gel bead as the thickness of the outer layer was increased to $2.68 \pm 0.29,2.96 \pm 0.32$, and 3.28 $\pm 0.29 \mathrm{~mm}$, respectively (Fig. S2). The OUR was increased according to the thickness (Fig. 1). Although the thick outer layer may inhibit the mass transfer efficiency, by constructing a thicker outer layer, the initial ammonia-oxidizing activity, as well as the mechanical strength, can be enhanced, due to the high PVA concentration.

However, the strategy to increase the nitrifying activated sludge concentration in the cross-linking reaction was proven to be the most effective method to facilitate the initial nitrifying activity in this study. A change in the VSS concentration from $765 \pm$ 9 to $4,219 \pm 34 \mathrm{mg}-\mathrm{VSS} / \mathrm{L}$ was tested at a fixed PVA concentration of $12.5 \%$. The nitrifying activated sludge concentration increase led to a thicker outer layer, as shown in Fig. 2, possibly due to the increased viscosity of the PVA/alginate solution [9]. The increase in the nitrifying activated sludge concentration resulted in a dramatic increase in the initial ammonia-oxidizing activity, i.e., OUR, in comparison with the results of the PVA concentration control (Fig. 1). The highest OUR was $10.5 \mathrm{mg}-\mathrm{DO} / \mathrm{L} \cdot \mathrm{h}$, which corresponds to the highest VSS concentration of 4,219 mg-VSS/L. Interestingly, the excellent linearity between nitrifying activated sludge content and OUR was maintained within the range of 0.02 to $0.13 \mathrm{mg}-\mathrm{VSS}$ per bead (Fig. 1). Nevertheless, at a high nitrifying activated sludge content of $0.23 \mathrm{mg}$-VSS per bead, a retarded slope of the initial

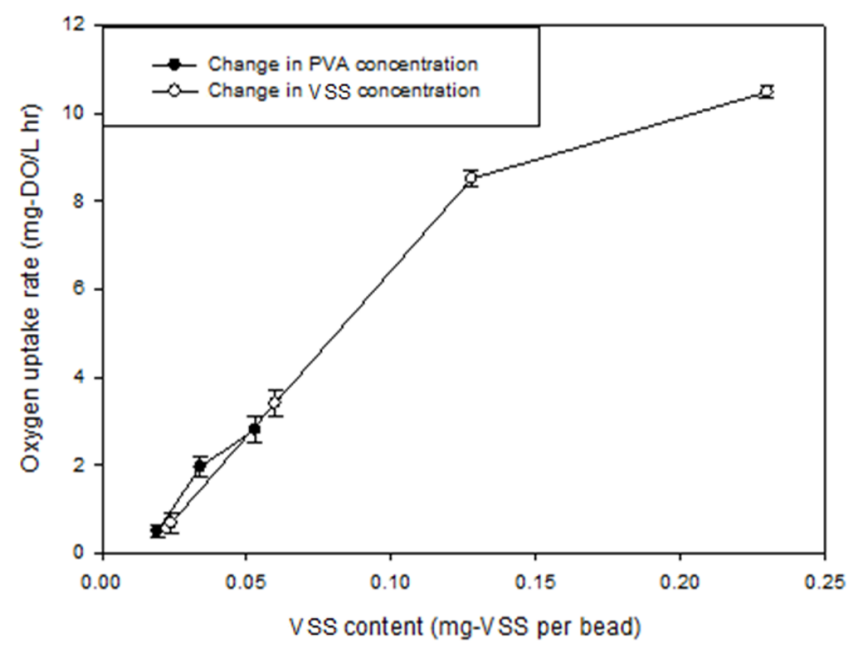

Fig. 1. The relationship between oxygen uptake rate and VSS content per bead when the PVA and VSS concentration were adjusted during the construction of the outer layer. 


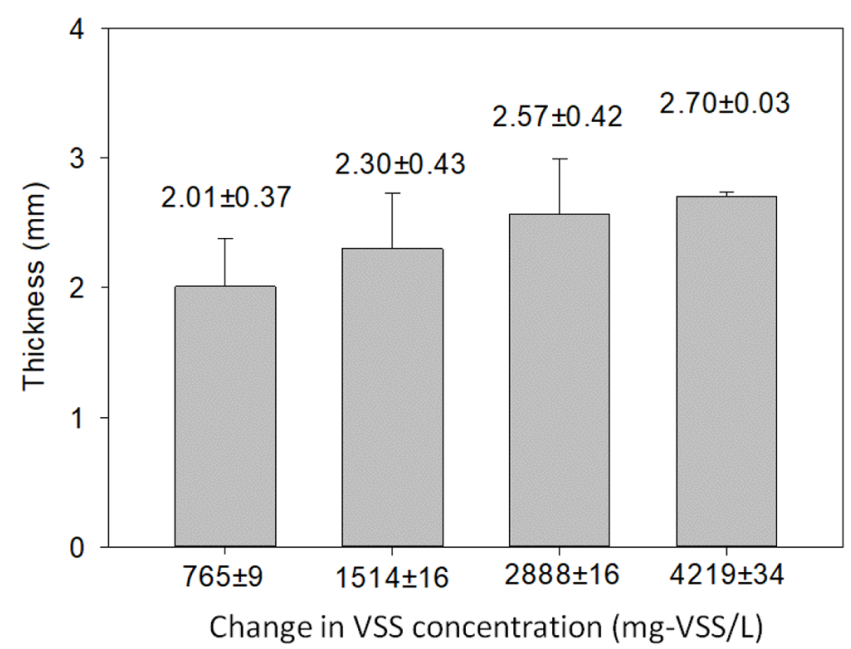

Fig. 2. The increase in the thickness of the outer layer according to the VSS concentration.

ammonia-oxidizing activity was found. This implies that the AOB is not fully activated when a large amount of nitrifying activated sludge exceeding $0.13 \mathrm{mg}$-VSS per bead.

In the previous result, the AOB density was proven to decide the oxygen penetration depth (OPD) in the range of 200-300 $\mu \mathrm{m}$ for $10^{6}$ cells of Nitrosomonas sp. [30]. Besides, the OPD could be differentiated depending on the respiration activity of various bacterial species. For example, a dominant ammonia-oxidizing bacterial community for saline nitrogenous wastewater was shown as Nitrosospira, Nitrosovibrio, and Nitrosococcus [31].

As a result, it was concluded that the nitrifying activated sludge concentration in the outer layer was the dominant factor for oxygen consumption by nitrifying activated sludge. The high nitrifying activated sludge loading is preferred for the protection of AMX bacteria from oxygen inhibition due to limited oxygen penetration. The oxygen penetration would be even more limited after the enrichment of AOB in the outer layer. Thus, the vertical oxygen profile in the outer layer was analyzed before and after the AOB enrichment using a continuous MBBR.

\subsection{Effect of $A O B$ Enrichment on $O P D$}

As the aeration cost is directly correlated with the operational costs and excessive DO concentration was not recommended [32-34]. The favorable DO level for the single-stage PN-AMX process is at a moderate level of $1 \sim 2 \mathrm{mg} / \mathrm{L}[35,36]$. The enrichment of AOB in the outer layer was conducted at a DO level of $2.0 \mathrm{mg} / \mathrm{L}$, in this study. In our previous study, the OPD in the outer layer containing 2,441 $\pm 238 \mathrm{mg}-\mathrm{VSS} / \mathrm{L}$ of $\mathrm{AOB}$ was determined to be 83 to $1,250 \mu \mathrm{m}$, which was proportional to the DO concentration in the bulk phase of 0.5 to $8 \mathrm{mg} / \mathrm{L}$ [14]. However, the effect of enrichment on the OPD has not yet been investigated. In this study, it has been hypothesized that oxygen penetration is less effective after enrichment due to the enhanced. Fig. 3 showed the enrichment of AOB in the continuous nitrifying reactor. The nitrifying activated sludge exhibited a linear increase in the ammonia-oxidation rate from 0.17 to $0.65 \mathrm{~kg}-\mathrm{N} / \mathrm{m}^{3}$-d for $17 \mathrm{~d}$ with 52.4 and $101.1 \mathrm{mg}-\mathrm{NH}_{4}{ }^{+}-\mathrm{N} / \mathrm{L}$

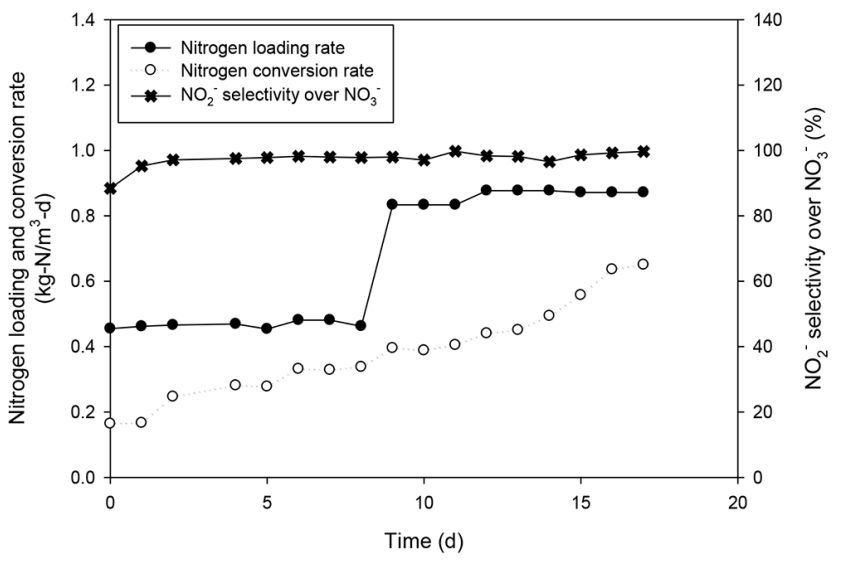

Fig. 3. Nitrogen loading and conversion rates during the enrichment of $\mathrm{AOB}$ and the selectivity of $\mathrm{NO}_{2}^{-}$over $\mathrm{NO}_{3}{ }^{-}$.

in the influent. The fact that the average selectivity for $\mathrm{NO}_{2}^{-}$over $\mathrm{NO}_{3}{ }^{-}$was $97.4 \pm 2.5 \%$ implied that the NOB activity was not significant during the enrichment. The detailed nitrogen composition of the influent and effluent are shown in Fig. S3. It is known that the low DO selectively activated the AOB activity over NOB by promoting the competition between $\mathrm{AOB}$ and $\mathrm{NOB}$ for the common substrate of DO. AOB can outcompete NOB in the low DO condition due to the high affinity for dissolved oxygen [37]. It was expected that the acclimation of $\mathrm{AOB}$ activity using the continuous nitrifying bioreactor resulted in the intensified AOB population in the outer layer. This could lead to reduced OPD in the outer layer. In fact, before enrichment, the OPD was at 966.7 \pm 52.3 to $66.7 \pm 34.7 \mu \mathrm{m}$ according to the different levels of DO (Fig. 4). After enrichment, the reduced OPD range was shown as $75.0 \pm 29.5$ to $333.3 \pm 36.4 \mu \mathrm{m}$, as expected. However, the insignificant effect of enrichment was identified on the OPD at low DO levels of 2.0 and $0.5 \mathrm{mg} / \mathrm{L}$. The reason for the insignificant OPD reduction is unclear. It was only speculated that low DO levels less than $2.0 \mathrm{mg} / \mathrm{L}$ result in insensitive variation of OPD, especially with the high initial concentration of nitrifying activated sludge in the outer layer $(2,441 \pm 238 \mathrm{mg}$-VSS/L in this study). Likely, the OPD range of $100 \sim 200 \mu \mathrm{m}$ is frequently reported in various nitrifying and single-stage PN-AMX processes at limited DO levels less than $2.0 \mathrm{mg} / \mathrm{L}[38,39]$.

For DO levels of 8 and $6 \mathrm{mg} / \mathrm{L}$, the OPD was significantly reduced from $966.7 \pm 52.3$ to $333.3 \pm 36.4$ and $510.4 \pm 14.6$ to 286.7 $\pm 37.1 \mu \mathrm{m}$, respectively, after the enrichment. As a result, the slope of DO penetration, which had been at $113.3 \mu \mathrm{m} / \mathrm{mg}-\mathrm{DO} \cdot \mathrm{L}$ for the initial nitrifying activated sludge, was reduced to $31.4 \mu$ m/mg-DO'L (Fig. 4). Thus, the enrichment can minimize the variation of OPD in the outer layer under the DO fluctuation in the single-stage PN-AMX process. Based on the OPD results, the minimal outer layer thickness of approximately $350 \mu \mathrm{m}$ is suggested, considering the maximum OPD of $333.3 \pm 36.4 \mu \mathrm{m}$ in this study. Various factors can control the OPD in the biofilm system. For example, a specific growth rate of Nitrosomonas sp. (r-strategist) could be faster than Nitrosospira sp. (i.e., K-strategist) with the same bulk phase substrate concentration depending on the different Monod's kinetic parameters [40]. Thus, it is expected that the OPD 


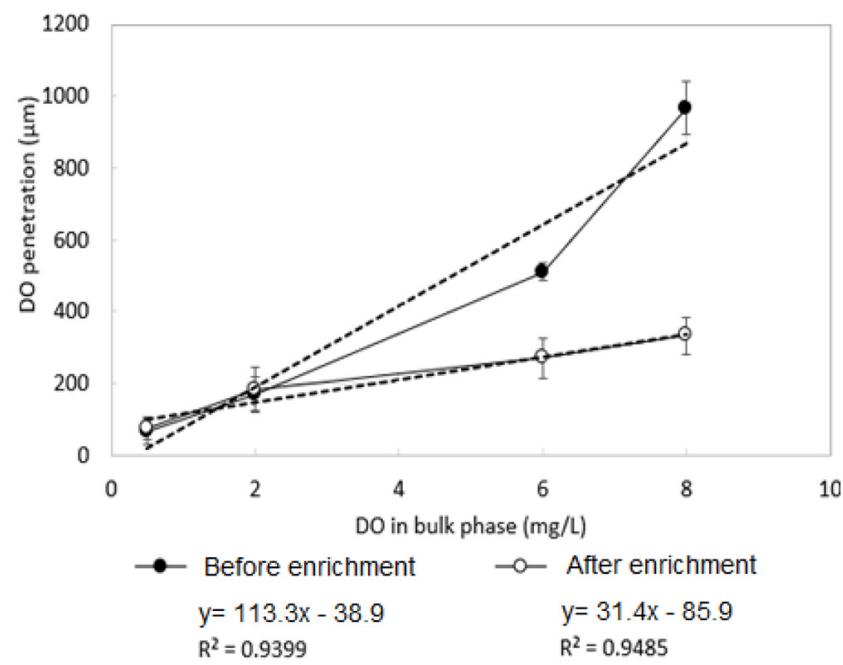

Fig. 4. Change in oxygen penetration depth through the outer layer before and after the enrichment of $\mathrm{AOB}$.

is narrower for Nitrosomonas sp. Than that of Nitrosospira sp. to the dominant AOB according to their differentiated oxygen uptake kinetics even with the same environmental conditions. Also, the biofilm thickness of $300 \mu \mathrm{m}$ was considered appropriate for the complete depletion of oxygen in the investigated relationship between OPD and biofilm thickness in a previous study [41]. As in the current study, the definition of oxygen penetration depth was based on the detect limitation of less than $0.2 \mathrm{mg} / \mathrm{L}$ of the microelectrode system. However, the active of Nitrosomonas europaea lineage in the DO concentration as low as $0.12 \mathrm{mg} / \mathrm{L}$ was proved in the research of Park et al. [42]. Instead of promoting the adaptation mechanisms, the depletion of DO concentration in the operation of the chemostat reactor created the favor condition on the selection of $\mathrm{AOB}$ community. Thus, the relationship between liable bacterial distribution and ODP needs further study.

\subsection{Bacterial Liability Distribution}

Recently, the live and dead cell staining assay and CLSM monitoring have widely been applied to assess the bacteria distribution [43]. In addition, the determination of live and dead cells was proved to be appropriate for AOB [44, 45]. In this study, the OPD is critically correlated with bacterial liability distribution in the outer layer. It was expected that liable nitrifying activated sludge is concentrated on the surface of the outer layer due to easier access to substrates, $\mathrm{NH}_{4}{ }^{+}$, and oxygen. The cross-section of the outer layer revealed that the live cells were dominant within $95 \mu \mathrm{m}$ (Fig. S4 and S5). As shown in Fig. 5, the density of the dead cells was consistent at a fluorescence level of $10^{5}$ across the depth of the gel bead. The death rates for AOB and NOB were calculated as 0.076 and $0.054 \mathrm{~d}^{-1}$, respectively, by the live and death staining method in a previous study [44]. This implies that the acclimation of the grown AOB as dead cells is faster than NOB in the PVA/alginate matrix. The high sludge retention time, due to entrapment in the PVA gel, contributed to the acclimation of the dead cells by preventing washout. In contrast, the concentration of the live cells was gradually reduced with depth probably due to the limitation of

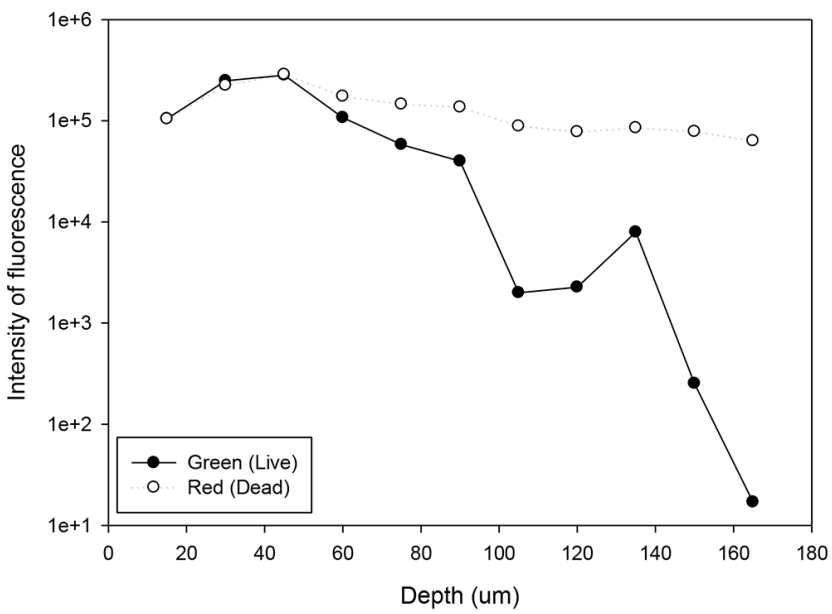

Fig. 5. The intensity of fluorescence densities of live and dead cells, according to the depth of the outer layer after the AOB enrichment

substrates (oxygen and ammonia). As shown in Fig. 5, the observation of live cells was limited within $165 \mu \mathrm{m}$. Based on this observation, the suggested minimal thickness of the outer layer at $350 \mu \mathrm{m}$ would be feasible, without interrupting the required active zone for the ammonia-oxidation processes. The limited liable cell distribution was narrower than the maximum OPD of 333.3 $\pm 36.4 \mu \mathrm{m}$. The reason for the limited liable cell distribution is not clear. However, the nitrifying biofilm is clearly thin than those of previous results. For example, the active nitrifying biofilm thickness is reported as $\sim 400 \mu \mathrm{m}$ in the case of the PN-AMX process [46]. Thus, it is considered that the nitrifying biofilm of this study was not fully developed and thinner than the matured nitrifying biofilm. As a result, the oxygen diffused over the barrier of thin liable nitrifying activated sludge cells which were condensed within $95 \mu \mathrm{m}$ at the high DO concentration of $8 \mathrm{mg} / \mathrm{L}$. The oxygen between 95 and $350 \mu \mathrm{m}$ can be consumed by the respiration activity of a liable nitrifying bacterial community which shows marginal fluorescence level.

\section{Conclusions}

To optimally design the outer layer of the core-shell structured PVA hydrogel beads for the single-stage PN-AMX process, the present study considered factors such as the PVA concentration, nitrifying activated sludge loading in the outer layer, and OPD. A high concentration of nitrifying activated sludge was entrapped in the outer layer for the rapid stabilization of the single-stage PN-AMX removal. The positive relationship between the initial oxygen consumption rate and the nitrifying activated sludge loading in the outer layer was revealed. At a low DO concentration of $2.0 \mathrm{mg} / \mathrm{L}$, the nitrogen removal rate was achieved at $0.65 \mathrm{~kg}-\mathrm{N} / \mathrm{m}^{3}-\mathrm{d}$ in the outer layer after 17 days of enrichment. The maximum OPD was significantly reduced from $966.7 \pm 52.3$ to $333.3 \pm 36.4$ $\mu \mathrm{m}$ at a DO level of $8.0 \mathrm{mg} / \mathrm{L}$ after AOB enrichment. Besides, after enrichment, the OPD, according to the bulk phase DO, was less sensitive and limited to a shallow range, i.e., 75.0 333.3 $\mu \mathrm{m}$. This implies that the effective protection of AMX bacteria from oxygen 
inhibition is feasible after AOB enrichment. The live cells were observed within a range of $165 \mu \mathrm{m}$ deep in the outer layer using both live and dead cell staining. Based on the results of the OPD and liable cell distribution, the minimal thickness of the outer layer was suggested to be approximately $350 \mu \mathrm{m}$, which secures the protection of the AMX bacteria given DO fluctuations.

\section{Acknowledgment}

This work was partly supported by the Korea Institute of Energy Technology Evaluation and Planning (KETEP) grant funded by the Korea government (MOTIE) (No. 20194110100100, Full-scale feasibility study of the stability and efficiency improvement of a biogas production facility based on biomass from urban/living environments).

\section{Author Contributions}

NTM (M.S. student) mainly wrote and revised this manuscript. MC (Research Scientist) conducted all of the experiments. NP (Researcher) supported the discussion based on the literature survey. HB (Assistant Professor) prepared the main storyline, the core discussion and revised the manuscript.

\section{References}

1. Do H, Lim J, Shin SG, Wu YJ, Ahn JH, Hwang S. Simultaneous effect of temperature, cyanide, and ammonia-oxidizing bacteria concentrations on ammonia oxidation. J. Ind. Microbiol. Biotechnol. 2008;35(11):1331-1338.

2. Qian W, Peng YZ, Li XJ, Zhang Q, Ma B. The inhibitory effects of free ammonia on ammonia-oxidizing bacteria and nitrite-oxidizing bacteria under anaerobic condition. Bioresour. Technol. 2017;243:1247-1250.

3. Cua LS, Stein LY. Effects of nitrite on ammonia-oxidizing activity and gene regulation in three ammonia-oxidizing bacteria. FEMS Microbiol. Lett. 2011;319(2):169-175.

4. Geets J, Boon N, Verstraete W. Strategies of aerobic ammonia-oxidizing bacteria for coping with nutrient and oxygen fluctuations. FEMS Microbiol. Ecol. 2006;58(1):1-13.

5. Kim WK, Rong C, Deokjin J. Enrichment of ammonia-oxidizing bacteria for efficient nitrification of wastewater. J. Microbiol. Biotechnol. 2005;15(4):772-779.

6. Egli K, Langer C, Siegrist HR, Zehnder AJB, Wagner M, Jan Roelof van der Meer. Community analysis of ammonia and nitrite oxidizers during start-up of nitritation reactors. Appl. Environ. Microbiol. 2003;69(6):3213-3222.

7. Munz G, Lubello C, Oleszkiewicz JA. Factors affecting the growth rates of ammonium and nitrite-oxidizing bacteria. Chemosphere 2011;83(5):720-725

8. Han W, Peng Z, Li T, Fan P, Yu L. Control of sludge settleability based on organic load and ammonia nitrogen load under low dissolved oxygen. Water Sci. Technol. 2018;78(10):2113-2118.

9. Bae H, Choi MK, Chung YC, Lee SK, Yoo YJ. Core-shell structured poly (vinyl alcohol)/sodium alginate bead for single-stage autotrophic nitrogen removal. Chem. Eng. 2017;322:408-416.

10. Dolejš I, Stloukal R, Rosenberg M, Rebroš M. Nitrogen removal by co-immobilized anammox and ammonia-oxidizing bacteria in wastewater treatment. Catalysts. 2019;9(523):1-8.

11. Dong YW, Zhang YQ, Tu BJ. Immobilization of ammonia-oxidizing bacteria by polyvinyl alcohol and sodium alginate. Braz. 2017;48:515-521.

12. Chou WP, Tseng SK, Ho CM, Wu ZZ, Feng YJ, Hsia TH. Highly efficient partial nitrification by polyvinyl alcohol-alginate immobilized cells. J. Chin. Inst. Eng. 2010;35(6):793-801.

14. Lertsutthiwong P, Boonpuak DCW, Pungrasmi WBL, Powtongsook S. Int. J. Environ. Sci. 2013;25(2):262-267.

15. Bae H, Choi MK. A shell layer entrapping aerobic ammonia-oxidizing bacteria for autotrophic single-stage nitrogen removal. Environ. Eng. Res. 2019;24(3):376-381.

16. Morales N, Val DRA, Vázquez-Padín JR, Méndez R, Mosquera-Corral A, Campos JL. Integration of the anammox process to the rejection water and main-stream lines of WWTPs. Chemosphere 2015;140:99-105.

17. Zhang M, Wang S, Ji B, Liu Y. Towards mainstream deammonification of municipal wastewater: Partial nitrification-anammox versus partial denitrification-anammox. Sci. Total Environ. 2019;692:393-401.

18. Zhang Z, Zhang Y, Chen YG. Recent advances in partial denitrification in biological nitrogen removal: from enrichment to application. Bioresour. Technol. 2019;298:122444.

19. Lackner S, Gilbert EM, Vlaeminck SE, Joss A, Horn H, van Loosdrecht MCM. Full-scale partial nitritation/anammox experiences -An application survey. Water Res. 2014;55:292-303.

20. Wett B. Development and implementation of a robust deammonification process. Water Sci. Technol. 2007;56(7):81-88.

21. Lackner S, Horn H. Evaluating operation strategies and process stability of a single-stage nitritation-anammox SBR by use of the oxidation-reduction potential (ORP). Bioresour. Technol. 2012;107:70-77.

22. Fuchs W, Bierbaumer D, Schöpp T, Weissenbacher N, Bousek J. New hybrid reactor concept incorporating a filter mesh for nitritation-anammox treatment of sludge return liquid. Water Sci. Technol. 2017;76(6):1409-1417.

23. Egli K, Fanger U, Alvarez PJJ, Siegrist H, van der Meer JR, Zehnder AJB, Enrichment and characterization of an anammox bacterium from a rotating biological contactor treating ammonium-rich leachate. Arch. Microbiol. 2001;175(3):198-207.

24. Woebken D, Fuchs BM, Kuypers MMM, Amann R. Potential interactions of particle-associated anammox bacteria with bacterial and archaeal partners in the Namibian upwelling system. Appl. Environ. Microbiol. 2007;73(14):4648-4657.

25. Kimura Y, Isaka K, Kazama F. Tolerance level of dissolved oxygen to feed into anaerobic ammonium oxidation (anammox) reactor. JWET. 2011;9(2):169-178.

26. Tao C, Hamouda MA. Steady-state modeling and evaluation of partial nitrification-anammox (PNA) for moving bed biofilm reactor and integrated fixed-film activated sludge processes treating municipal wastewater. J. Water Process Eng. 2019; 31:100854.

27. Yang AMJ, Trela J, Plaza E. Combination of upflow anaerobic 
sludge blanket (UASB) reactor and partial nitritation/anammox moving bed biofilm reactor (MBBR) for municipal wastewater treatment. Bioresour. Technol. 2015;180:144-153.

28. Zhang L, Zheng P, Tang CJ, Jin RC. Anaerobic ammonium oxidation for the treatment of ammonium-rich wastewaters. J. Zhejiang Univ. Sci. B. 2008;9(5):416-426.

29. Bae H, Yang H, Chung YC, Yoo YJ, Lee S. High-rate partial nitritation using porous poly(vinyl alcohol) sponge. Bioprocess Biosyst. Eng. 2014;37(6):1115-1125.

30. Bae Y, Chung YC, Yang H, Lee C, Aryapratama R, Yoo YJ, Lee S. Assessment of bacterial community structure in nitrifying biofilm under inorganic carbon-sufficient and -limited conditions. J. Environ. Sci. Health A Tox. Hazard Subst. Environ. Eng. 2015;50(2):201-212.

31. Ufmoto H, Ando A, Saiki H. Effect of oxygen concentration on nitrogen removal by Nitrosomonas europaea and Paracoccus denitrificans immobilized within tubular polymeric gel. J. Biosci. Bioeng. 2000;90(6):654-660.

32. del Rio AV, Pichel, A, Fernandez-Gonzalez N, et al. Performance and microbial features of the partial nitritation-anammox process treating fish canning wastewater with variable salt concentrations. J. Environ. Manage. 2018;208:112-121.

33. Rosso D, Stenstrom MK, Larson LE. Aeration of large-scale municipal wastewater treatment plants: state of the art. Water Sci. Technol. 2008;57(7):973-978.

34. Liu C, Li S, Zhang F. The oxygen transfer efficiency and economic cost analysis of the aeration system in municipal wastewater treatment plant. Energy Procedia. 2011;5:2437-2443.

35. Drewnowski J, Remiszewska-Skwarek A, Duda S, Łagód G. Aeration process in bioreactors as the main energy consumer in a wastewater treatment plant. Review of solutions and methods of process optimization. Processes 2019;7:311.

36. Cao YS, van Loosdrecht MCM, Daigger GT. Mainstream partial nitritation-anammox in municipal wastewater treatment: status, bottlenecks, and further studies. Appl. Microbiol. Biotechnol. 2017;101(4):1365-1383.

37. Kunapongkiti P, Rongsayamanont C, Nayramitsattha P, Limpiyakorn T. Application of cell immobilization technology to promote nitritation: A review. Environ. Eng. Res. 2020;25: 807-818.

38. Ruiz G, Jeison D, Rubilar O, Ciudad G, Chamy R. Nitrification-denitrification via nitrite accumulation for nitrogen removal from wastewaters. Bioresour. Technol. 2006;97:330-335.

39. José Ramón Vázquez Padín. Autotrophic nitrogen removal in granular sequencing batch reactors. [dissertation]. Santiago: Univ. of Santiago de Compostela; 2009.

40. Stewart PS, Zhang T, Xu R, et al. Reaction-diffusion theory explains hypoxia and heterogeneous growth within microbial biofilms associated with chronic infections. NPJ Biofilms Microbiomes. 2016;16012.

41. Terada A, Sugawara S, Yamamoto T, Zhou S, Koba K, Hosomi M. Physiological characteristics of predominant ammonia-oxidizing bacteria enriched from bioreactors with different influent supply regimes. Biochem. Eng. J. 2013;79:153-161.

42. Hibiya K, Nagai J, Tsuneda S, Hirata A. Simple prediction of oxygen penetration depth in biofilms for wastewater treatment. Biochem. Eng. J. 2004;19(1):61-68.

43. Park HD, Noguera DR. Evaluating the effect of dissolved oxygen on ammonia-oxidizing bacterial communities in activated sludge. Water Res. 2004;38:3275-3286.

44. Ge J, Wang S, Yang X, Qiu S, Li B, Peng Y. Detection of nitrifiers and evaluation of partial nitrification for wastewater treatment: A review. Chemosphere 2015;140:85-98.

45. Hao X, Wang Q, Zhang X, Cao Y, van Loosdrecht MCM. Experimental evaluation of decrease in bacterial activity due to cell death and activity decay in activated sludge. Water Res. 2009;43(14):3604-3612.

46. Wahman DG, Wulfeck-Kleier KA, Pressman JG. Monochloramine disinfection kinetics of Nitrosomonas europaea by propidium monoazide quantitative PCR and Live/Dead BacLight methods. Appl. Environ. Microbiol. 2009;75(17):5555-5562.

47. Almstrand R, Persson F, Daims H, et al. Three-Dimensional Stratification of Bacterial Biofilm Populations in a Moving Bed Biofilm Reactor for Nitritation-Anammox. Int. J. Mol. Sci. 2014;15(2):2191-2206. 